\title{
Decision-Making Quality towards Effectiveness of Conciliation Process of Lupong Tagapamayapa
}

\author{
Jan Fritz M. Villamor ${ }^{1}$, Ronel G. Dagohoy ${ }^{2}$ \\ ${ }^{1}$ Student, Bachelor of Arts in Psychology, Ateneo de Davao University \\ ${ }^{2}$ Program Chairperson, Bachelor of Public Administration at Institute of Leadership, Entrepreneurship and Good Governance, \\ Davao del Norte State College
}

\begin{abstract}
This study assessed the decision making quality towards the effectiveness of conciliation process of lupong tagapamayapa. The main purpose and objective of this study is to determine which domain of decision making quality significantly influences the effectiveness of conciliation process of lupong tagapamayapa. This study used the descriptivecorrelational method of research. This study was conducted in Barangay Tibal-og, Santo Tomas, Davao del Norte, Philippines and it has 100 respondents through quota sampling, who are the constituents of the barangay who availed the services of the lupong tagapamayapa. The researchers adopted two questionnaires from online sources, which were validated through pilot testing. The results have shown that the level of the decision making quality of lupong tagapamayapa is very high, additionally the results also revealed that the level of the effectiveness of conciliation process of lupong tagapamayapa is very high. The study also resulted that decision making quality and effectiveness of conciliation process of lupong tagapamayapa has a positive high significant correlation and lastly, it was found out that evaluation is the domain of the decision making quality that significantly influences effectiveness of conciliation process of Lupong Tagapamayapa. The result of the study will be used to make interventions and programs to maintain and continue the efficiency and effectiveness of lupong tagapamayapa.
\end{abstract}

Keywords - Decision Making Quality, Effectiveness of Conciliation Process, Lupong Tagapamayapa, Philippines

\section{INTRODUCTION}

\subsection{Background of the Study}

Lupong Tagapamayapa, under the Barangay Justice System, had been working and operating in the Philippines for more than a decade. It effectively resolved disputes and conflicts happening in a barangay [1]. However, lupong tagapamayapa are still facing various problems. They have insufficient training and seminars about the barangay justice system that lead to improper conciliation process and unsatisfied constituents [2]. Also, there are numerous instances of case recurrence in Lupong with the same persons involved in the dispute because of the inefficient conciliation process [3]. Furthermore, due to the unwillingness of one party to participate in the conciliation, conciliators find difficulties in reaching progress, thus leading to unresolved cases [4].

Despite the issues faced by the lupong tagapamayapa, they still continue to serve and help the community and the barangay in settling disputes and conflicts. In fact, more than $80 \%$ of the cases filed in a barangay in Tarlac were resolved
[2]. It also gave easy access to justice and resolved congestions in the courts [5]. Lupong also assisted the conflict-affected areas such as Maguindanao to immediately reconcile conflicts in the area without the high-cost litigation [6]. It also retains the right of the parties to withdraw from conciliation to any point of the proceedings without prejudice to their legal status per se, and it is committed to maintaining confidentiality throughout the proceedings, and consequently, to resolving the conflict, the details exchanged, and the resolution reached [7].

There are various studies about the effectiveness of the conciliation process of lupong tagapamayapa that link to different factors. On the other hand, the efficiency of the conciliation process depends on the decision-making skills of the conciliator or the lupong, and how it resolves a dispute between two parties [7]. Decision-making processes play a significant role in conciliation; it creates a broader framework for sorting, questioning, and solving a dispute [8]. The conciliator needs to have good analytical skills to deal with complex problems, if possible, he must break them up into manageable parts to identify and explore alternatives and possible solutions to resolve the dispute [9].

Given the above incidents, the lupong tagapamayapa has gradually lost their authority, legitimacy, and credibility to conduct conciliation and to resolve disputes. Thus, the researchers find the urgency to conduct this research study for them to know if such situations are happening in the local area and if the lupong are really working and operating and effectively resolve disputes in the barangay.

The findings of the study will give significant details to organizations such as the Department of the Interior and Local Government (DILG) and will give them pieces of information on how effective lupong tagapamayapa is in the barangay. Moreover, this study also significantly contributes to bringing improvements to the conciliation process of the Lupong.

\subsection{Theoretical Framework}

The researchers wanted to know the relationship between the decision-making quality and the effectiveness of the conciliation process of lupong tagapamayapa. To have a clear understanding about the variables, this research is anchored on the following credible authorities: 
Lupong Tagapamayapa is established pursuant to the law of the Republic Act (R.A.) No. 7160 also known as the Local Government Code of 1991, in which Article 387(b) of the Law specifies that a lupong tagapamayapa shall be established in every barangay. The lupong consists of the punong barangay president and 10 to 20 members. A lupong member must be a citizen or barangay employee who is not otherwise specifically excluded by law and has integrity, impartiality, independence of mind, a sense of fairness, and a reputation for integrity. Lupong tagapamayapa is an alternative dispute resolution in a barangay, they settle conflicts and misunderstandings without the costly application of cases in higher courts [10].

The concept is also supported by the Decision Theory of Hansson [11], which stated that there are two types of decision-making theory, normative and descriptive. Normative suggests how decisions should be made, while descriptive describes how decisions are actually made. It also stated that normative decisions lead to rational decision making or an effective and unbiased quality of the decision.

The research study is also anchored on the Procedural Justice Theory of 1990, and it stated that the fairness and effectiveness of dispute and conflict-resolution, depends on the quality of the decision-making process of the power holder or a person with authority [12]. This theory is found applicable in our study because it suggests that achieving an effective and fair conciliation process, the power-holder or the conciliator should have rational and good decision-making skills.

\subsection{Conceptual Framework}

Figure 1 reveals the conceptual framework of the study. The first box contains the independent variable, which is the decision-making quality of the lupong tagapamayapa and its indicators, while the second box contains the dependent variable, which is the effectiveness of the conciliation process of lupong tagapamayapa and its indicators. For the independent variable, decision-making quality was classified into four, namely, structure and approach, evaluation, impact and transparency and communication [13]. For the dependent variable, the effectiveness of the conciliation process of the lupong tagapamayapa was classified into four, namely, conciliation efforts to reconcile parties, issuance of certificate to file action, enforcement of rules and proper application of the legal procedures [1].

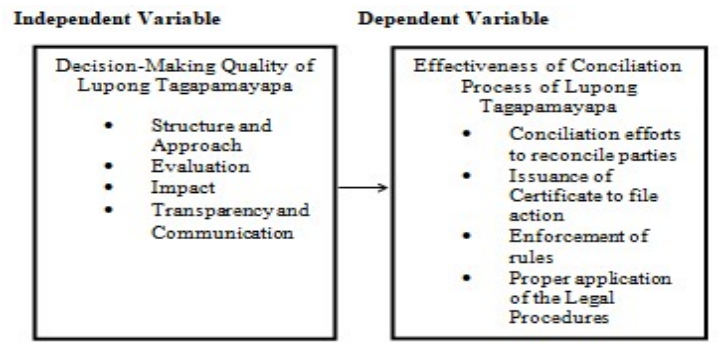

Figure 1. Conceptual Framework Showing the Variables of the Study
The quality of the decision-making of a lupong should be fair and rational in order to achieve an effective conciliation process in the lupong tagapamayapa [1]. The following indicators of the independent variable were discussed below.

Structure and Approach. A regulatory body's ability to achieve its legislative goals, including protecting the public interest, is closely linked to sound decision-making based on clear policy and well-defined policies. It is management's responsibility to ensure that decisions are consistent with the regulatory body's strategy and consistent with other decisions based on similar facts. If this obligation is not understood and met, the importance of control for society will be significantly diminished [14].

Evaluation. Evaluating the decision is significant because there are several key factors affecting decision-making. Important factors include past experiences, a number of cognitive biases, increased engagement and lowered results, the individual differences, which includes age and socioeconomic status, and a confidence in personal importance. All these things affect the decision-making process and the decisions that have been made [15].

Impact. Decisions may have positive or negative effects. In demonstrating the positive impact of experience and the negative impact of uncertainty, decision-making elements can be influenced along with the various impacts that can arise from a single resource and its sequential emergence [16].

Transparency and Communication. The organization's chief executive and senior management should receive a wide range of input from both internal and external sources to make good decisions that would push the organization forward. Customer, supplier, and employee information is essential for successful decision-making [17].

Achieving an effective conciliation process is a difficult situation, in order to reconcile disputes and conflicts, the conciliator or the lupong should have rational and good analytical skills [1]. The following indicators for the dependent variable were discussed below.

Conciliation process to reconcile parties. The true value of conciliaation occurs when the parties fully trust the conciliator to the degree that they share their thought, strategy, and ultimate goals in the conflict honestly and openly. It positions the conciliator's responsibility to act in a manner that creates trust, is freely unbiased, is moral, and is consistently capable of maintaining confidentiality [9].

Issuance of Certificate to file action: Filing certifications to file action is one of the steps in a conciliation process. It can be before the settlement of the dispute and after. During and when the parties arrive at the harmonious settlement of the disputes, the conciliator and the parties receive a duly authenticated copy (by the conciliator) of the settlement agreement, it is the responsibility of the lupong tagapamayapa to issue a certificate to file action [7]. 
Enforcement of rules.: It is a matter of policy for lupong to be procedural in the exercise of its powers and duties to review and resolve cases brought before its jurisdiction with a view to harmoniously resolving conflicts. The lupong needs to follow and enforce rules to achieve effective conciliation [1].

Proper Application of the Legal Procedures: It is a general finding of this study that the members of the lupong are confident that they will discharge their exceptional efforts. By being conscious and sufficiently disciplined about their mandated roles, functions and responsibilities to make every conciliation process successful by observing all the considered aspect of effectiveness. In addition, the lupong is readily available and accommodating in providing greater fulfillment of its responsibilities regarding with the existing provisions of the law to ensure that disputes are compulsory and binding on the parties to the conciliation process [1].

\subsection{Research Objectives}

This paper intends to find out if there is an existing relationship between the quality of decision-making and the effectiveness of the conciliation process of the lupong tagapamayapa. Specifically, it attempted:

1. To describe the level of decision-making quality of the lupong tagapamayapa in terms of:

1.1 Structure and Approach;

1.2 Evaluation;

1.3 Impact; and

1.4 Transparency and Communication.

2. To describe the level of effectiveness of conciliation process of lupong tagapamayapa in terms of:

2.1 Conciliation efforts to reconcile parties;

2.2 Issuance of certificate to file action;

2.3 Enforcement of rules; and

2.4 Proper application of the legal procedures.

3. To ascertain the significant relationship between decisionmaking quality and effectiveness of the conciliation process of the lupong tagapamayapa in Barangay Tibal-og.

4. To determine which domain of decision-making quality of the lupong tagapamayapa significantly influences the effectiveness of the conciliation process.

\subsection{Hypotheses}

1. There is no significant relationship between the decisionmaking quality and the effectiveness of the conciliation process of the lupong tagapamayapa in Barangay Tibalog.

2. There is no domain of decision-making quality that significantly influences the effectiveness of the conciliation process of the lupong tagapamayapa.

\subsection{Research Design}

\section{METHODOLOGY}

This study utilized the descriptive-correlational method of research to determine the relationship between the quality of decision-making and the effectiveness of the conciliation process of Lupong Tagapamayapa. Descriptive-correlational design involves the calculation of two or more relevant variables and the assessment of the relationship between or between these variables [18]. It is a study in which the researcher is primarily interested in defining relationships between variables, without attempting to establish a causal link [19].

\subsection{Research Locale}

The study was conducted in Barangay Tibal-og, located at the Municipality of Santo Tomas, Davao del Norte. Barangay Tibal-og is the biggest and main barangay in Santo Tomas, having 48, 034 people, 10,099 households and 11,030 families (BNS/BHW Actual Survey, 2019).

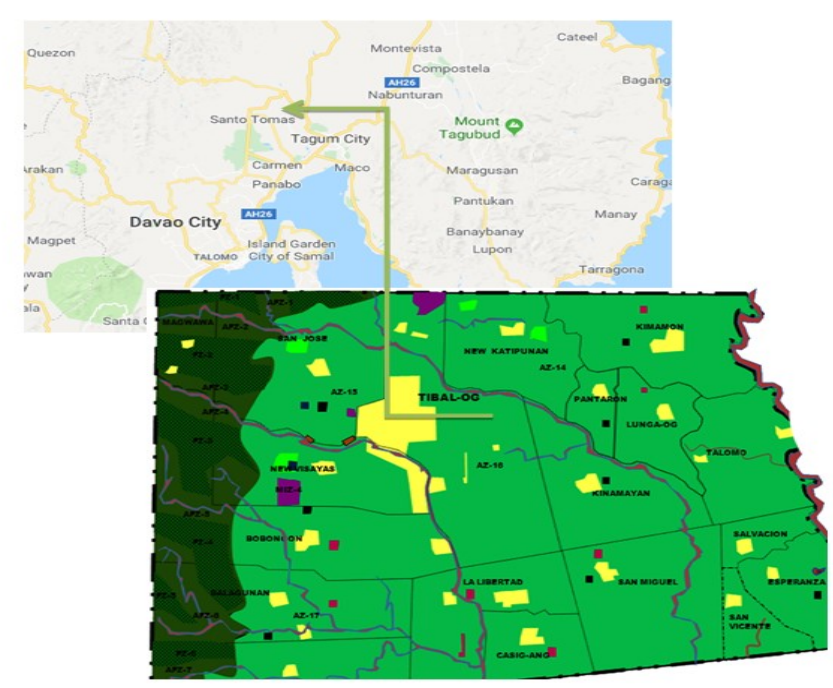

Figure 2: Barangay Tibal-og, Santo Tomas, Davao del Norte Map

\subsection{Research Respondents}

The respondents of the study were the constituents who availed the services of lupong tagapamayapa for three consecutive times, only from the year 2013 up to present, which was said to be the start of the administration of the present administration.

The study used purposive quota sampling technique on identifying the participants; it is used to determine the sample size from the population of the study. Purposive quota sampling is a technique commonly used to define and pick information-rich cases for the most effective use of limited resources. It includes finding and choosing individuals or groups of individuals who are particularly familiar with or comfortable with an interesting phenomenon, it also refers to selection of units based on personal judgement rather than 
randomization [20]. Through purposive sampling, there will be 100 respondents of the study.

\subsection{Data Gathering Procedures}

The researcher personally distributed and administered the research instrument to the respondents to ensure one hundred $(100 \%)$ percent retrieval of the questionnaire. The survey was conducted on the second semester of school year 2019-2020. Permission letter was delivered and directly approved by the Municipal Local Government Operations Officer of Santo Tomas, Ma'am Rose Ann Macabontoc. The data that was gathered by the researchers were tallied, tabulated, analyzed and interpreted based on the purpose of the study.

\subsection{Statistical Treatment}

The following statistical tools were used in the computation of data and testing the hypotheses at alpha 0.05 level of significance.

Mean. This was used to determine the level of decisionmaking quality and the level of the effectiveness of conciliation process of lupong tagapamayapa.

Pearson $r$ : This was used to determine the interrelationship between decision-making quality and effectiveness of conciliation process of lupong tagapamayapa.

Regression Analysis: This was used to determine the significant influence between decision-making quality towards effectiveness of conciliation process of lupong tagapamayapa.

\subsection{Research Instruments}

The researcher used two standardized questionnaires from the study Evaluating Quality of Decision-Making Processes in Medicines' Development, Regulatory Review, and Health Technology Assessment: A Systematic Review of the Literature by Bujar et al. and Effectiveness of Conciliation Process: A Practical Way of Delivering Justice by Agustin [13] [1].

Decision-making quality scale and Effectiveness of Lupong Tagapamayapa scale was designed to identify the factors of the quality of the decision-making that may influence the efficiency of the lupong tagapamayapa. The instrument consists of three parts, the first part is the personal information, the second part is the decision-making quality scale with 10 items and four subscales which are the structure and approach, evaluation, impact and transparency and communication. The last part consists the effectiveness of lupong tagapamayapa scale with 22 items and four subscales which are the conciliation efforts to reconcile parties, issuance of certificate to file action, enforcement of rules and proper application of the Legal Procedures.
Table I. Decision-Making Quality Scale

\begin{tabular}{ccc}
$\begin{array}{c}\text { Score } \\
\text { Intervals }\end{array}$ & $\begin{array}{c}\text { Descriptive } \\
\text { Equivalent }\end{array}$ & \multicolumn{1}{c}{ Interpretation } \\
$5.17-6.00$ & Very high & $\begin{array}{l}\text { This means that the good quality } \\
\text { of decision-making among } \\
\text { lupong is always manifested. }\end{array}$ \\
$4.34-5.16$ & High & $\begin{array}{l}\text { This means that the good quality } \\
\text { of decision-making among } \\
\text { lupong is oftentimes manifested. }\end{array}$ \\
$3.52-4.33$ & Minimun & $\begin{array}{l}\text { This means that the good quality } \\
\text { of decision-making among } \\
\text { lupong is manifested }\end{array}$ \\
$2.68-3.51$ & Low & $\begin{array}{l}\text { This means that the good quality } \\
\text { of decision-making among } \\
\text { lupong is sometimesmanifested }\end{array}$ \\
$1.84-2.67$ & Very low & $\begin{array}{l}\text { This means that the good quality } \\
\text { of decision-making among } \\
\text { lupong is seldom manifested. }\end{array}$ \\
$1.00-1.83$ & Extremely low & $\begin{array}{l}\text { This means that the good quality } \\
\text { of decision-making among } \\
\text { lupong is not manifested. }\end{array}$
\end{tabular}

The questionnaire was modified to include only the items relevant to the study. The draft was first shown to the researcher's adviser for comments and suggestions, after which experts were requested to validate the said questionnaire. After validation of the experts, the reliability of the questionnaire was tested through pilot testing Cronbach's Alpha. Cronbach's alpha reliability coefficient normally ranges between 0 and 1 . However, there is no lower limit to the coefficient. The closer Cronbach's alpha coefficient is to 1.0 , the greater the internal consistency of the items in the scale [21].

Decision-making quality scale generated a Cronbach's alpha of .776 higher than the required .70 for the reliability from the pilot- testing of the scale given to 30 respondents. The 6 Likert type scale was used to determine and interpret the data gathered. It is categorized into six levels, the table is shown above.

Table II. Effectiveness of Lupong Tagapamayapa Scale

\begin{tabular}{|c|c|c|}
\hline $\begin{array}{l}\text { Score } \\
\text { Intervals }\end{array}$ & $\begin{array}{l}\text { Descriptive } \\
\text { Equivalent }\end{array}$ & Interpretation \\
\hline $5.17-6.00$ & Very high & $\begin{array}{l}\text { This means that the effectiveness } \\
\text { of the lupong is always } \\
\text { manifested. }\end{array}$ \\
\hline $4.34-5.16$ & High & $\begin{array}{l}\text { This meansthat the effectiveness } \\
\text { of the lupong is oftentimes } \\
\text { manifested. }\end{array}$ \\
\hline $3.52-4.33$ & Minimum & $\begin{array}{l}\text { This means that the effectiveness } \\
\text { of the lupong is manifested. }\end{array}$ \\
\hline $2.68-3.51$ & Low & $\begin{array}{l}\text { This means that the effectiveness } \\
\text { of the lupong is sometimes } \\
\text { manifested }\end{array}$ \\
\hline $1.84-2.67$ & Very low & $\begin{array}{l}\text { This means that the effectiveness } \\
\text { of the lupong is seldom } \\
\text { manifested. }\end{array}$ \\
\hline $1.00-1.83$ & Extremely low & $\begin{array}{l}\text { This means that the effectiveness } \\
\text { of the lupong is not manifested. }\end{array}$ \\
\hline
\end{tabular}


While the effectiveness of lupong tagapamayapa scale garnered a Cronbach's alpha of .878 higher than the required .70 for the reliability from the pilot- testing of the scale given to 30 respondents. The results concluded that the questionnaire is reliable and can be used in gathering the data of the study. The 6 Likert-type scales were adopted to analyze and interpret the data. The scoring guide of the scales is divided into six levels. The scale is shown above.

\section{RESULTS AND DISCUSSIONS}

The gathered data has been carefully analyzed and interpreted. Result and discussion of findings on decision making quality and effectiveness of conciliation process of Lupong Tagapamayapa are presented below.

\subsection{Level of Decision Making Quality}

Shown in table 3 are the results for the decision-making quality of Lupong Tagapamayapa with an overall mean of 5.20 described as very high with a standard deviation of 0.64 . The very high level could be attributed to the very high rating given by the respondents in the majority of the indicators. This means that the good quality of decision-making among lupong is always manifested in the majority of cases in the items of structure and approach, evaluation, impact, and transparency and communication.

One measure of decision-making quality is evaluation, which garnered the lowest mean among the indicators with only 4.98 and a standard deviation of 0.80 which is described as high. This signifies that the lupong's evaluation on their decision is oftentimes manifested; it means that the lupong often evaluates the cognitive biases and factors affecting their decision.

Table III. Level of Decision-Making Quality of Lupong Tagapamayapa

\begin{tabular}{|c|c|c|c|}
\hline Dimensions & Mean & SD & Description \\
\hline Structure and Approach & 5.25 & 0.86 & Very High \\
\hline Evaluation & 4.98 & 0.80 & High \\
\hline Impact & 5.21 & 0.82 & Very High \\
\hline $\begin{array}{c}\text { Transparency and } \\
\text { Communication }\end{array}$ & 5.38 & 0.65 & Very High \\
\hline Overall mean & 5.20 & 0.64 & Very High \\
\hline
\end{tabular}

Legend:

$1.00-1.83$ Extremely low 2.68-3.51 Low $4.34-5.16$ High

-2.67 Very low $3.52-4.33$ Minimum5.17 -6.00 Very High

Furthermore, transparency and communication gained the highest score among the indicators with the mean score of 5.38 and standard deviation of 0.65 which is described as very high. This signifies that the lupong's transparency and communication on their constituents are always manifested. This means that lupong always communicates effectively and is transparent on their decisions on their constituents, thus leading to good and effective decision-making.
The results corroborate to the study conducted by Dietrich, which he stated that decisions are sometimes influenced by internal and external biases that is why it is important to conduct evaluations and analysis to achieve good decisionmaking [15]. In addition, it also verifies the statement of Cox et al., that the decisions should be transparent to the people, the decision maker should clearly communicate the information and the decisions being made in order for effectively achieving fair and rational decision-making [22].

\subsection{Level of Effectiveness of Conciliation Process of Lupong Tagapamayapa}

In table 4 reflected the responses of the respondents in the effectiveness of conciliation process of lupong tagapamayapa. The result shows an over-all mean of 5.27 and a standard deviation of 0.59 which is describe as very high. The result could be attributed to the very high rating given by the respondents in the majority of the indicators. This means that the effectiveness of conciliation process of lupong tagapamayapa is always manifested in the majority of cases in the items of conciliation efforts to reconcile parties, issuance of certificate to file action, enforcement of rules and proper application of the legal procedures.

The last indicator which is proper application of the legal procedures, has the highest weighted mean score of 5.38 with a standard deviation of 0.57 that resulted in a very high description level and is always manifested, this enfold that proper application of the legal procedures is an essential factor for the effective conciliation process of the lupong. Furthermore, issuance of certificate to file action garnered the lowest weighted mean among the variables with a mean score of 5.08 and standard deviation of 0.86 , which is described as a high description level and is oftentimes manifested, this means that issuance of certificate to file action is essential in achieving an effective conciliation process.

The results confirms the statement of Shinde that following the legal rules and procedures is essential in achieving the correct and effective conciliation process [7]. He further states that the two disputing parties should be brought together where they can interact and where the conciliator will arrive at the settlement of the dispute, the conciliator should also embody and follow exceptional efforts by being conscious and adequately conscientious about their prescribed duties, functions and obligations to make any conciliation process efficient by observing all the considered aspect of effectiveness [7]. Moreover, the results also validate the statement of Blignaut, which he stated that issuing certificates to file action before the conciliation and after settling disputes is essential in the successful and effective conciliation process [5].

Table IV. Level of Effectiveness of Conciliation Process of Lupong Tagapamayapa

\begin{tabular}{|c|c|c|c|}
\hline Dimensions & Mean & SD & Description \\
\hline $\begin{array}{c}\text { Conciliation efforts to } \\
\text { reconcile parties }\end{array}$ & 5.36 & 0.66 & Very High \\
\hline
\end{tabular}




\begin{tabular}{|c|c|c|c|}
\hline $\begin{array}{c}\text { Issuance of Certificate to } \\
\text { File Action }\end{array}$ & 5.08 & 0.86 & High \\
\hline Enforcement of Rules & 5.25 & 0.76 & Very High \\
\hline $\begin{array}{c}\text { Proper Application of } \\
\text { the Legal Procedures }\end{array}$ & 5.38 & 0.57 & Very High \\
\hline Overall mean & 5.27 & 0.59 & Very High \\
\hline
\end{tabular}

Legend:

$1.00-1.83$ Extremely low 2.68-3.51 Low 4.34-5.16 High

$1.84-2.67$ Very low $\quad 3.52-4.33$ Minimum $5.17-6.00$ Very High

\subsection{Significance of the Relationship between Decision-} Making Quality and Effectiveness of Conciliation Process of Lupong Tagapamayapa

Table 5 presents the summary of the computations of the correlation between decision-making quality and effectiveness of conciliation process of lupong tagapamayapa. It shows an overall computed r-value of 0.767 with a p-value of 0.000 . The result implies a positive high significant correlation between Decision-making quality and effectiveness of conciliation process of lupong tagapamayapa. The overall results of the correlation of measures indicate that there is a significant relationship between the two variables. Thus, the null hypothesis will be rejected. This implies that the decision-making quality of the lupong is relevant in achieving an effective conciliation process.

Table V. Significance on the Relationship between Decision-Making Quality and Effectiveness of Conciliation Process of Lupong Tagapamayapa

\begin{tabular}{|c|c|c|c|c|c|}
\hline \multirow[b]{2}{*}{$\begin{array}{l}\text { Decision- } \\
\text { Making } \\
\text { Quality }\end{array}$} & \multicolumn{5}{|c|}{ Effectiveness of Conciliation Process of Lupong Tagapamayapa } \\
\hline & $\begin{array}{c}\text { Conciliati } \\
\text { on efforts } \\
\text { to } \\
\text { Reconcil } \\
\text { e Parties }\end{array}$ & $\begin{array}{c}\text { Issuance } \\
\text { of } \\
\text { Certificat } \\
\text { e to File } \\
\text { Action }\end{array}$ & $\begin{array}{c}\text { Enforcemen } \\
\quad t \text { of } \\
\text { Rules }\end{array}$ & $\begin{array}{l}\text { Proper } \\
\text { Applicatio } \\
\mathrm{n} \text { of the } \\
\text { Legal } \\
\text { Procedures }\end{array}$ & $\begin{array}{c}\text { Overal } \\
1\end{array}$ \\
\hline \multirow{2}{*}{$\begin{array}{l}\text { Structure } \\
\text { and } \\
\text { Approach }\end{array}$} & $.793 * *$ & $.267 * *$ & $.462 * *$ & $.557 * *$ & $.604 * *$ \\
\hline & $(.000)$ & $(.007)$ & $(.000)$ & $(.000)$ & $(.000)$ \\
\hline \multirow{2}{*}{ Evaluation } & $.803 * *$ & $.451 * *$ & $.697 * *$ & $.589 * *$ & $.758 * *$ \\
\hline & $(.000)$ & $(.000)$ & $(.000)$ & $(.000)$ & $(.000)$ \\
\hline \multirow{2}{*}{ Impact } & $.697 * *$ & $.205^{* *}$ & $.614^{* *}$ & $.420 * *$ & $.569^{* *}$ \\
\hline & $(.000)$ & $(.041)$ & $(.000)$ & $(.000)$ & $(.000)$ \\
\hline \multirow{2}{*}{$\begin{array}{c}\text { Transparenc } \\
\text { y and } \\
\text { Communica } \\
\text { tion }\end{array}$} & $.749 * *$ & $.229 * *$ & $.544^{* *}$ & $.510^{* *}$ & $.593 * *$ \\
\hline & $(.000)$ & $(.022)$ & $(.000)$ & $(.000)$ & $(.000)$ \\
\hline \multirow{2}{*}{ Overall } & $.925 * *$ & $.352 * *$ & $.704 * *$ & $.631 * *$ & $.767 * *$ \\
\hline & $(.000)$ & $(.000)$ & $(.000)$ & $(.000)$ & $(.000)$ \\
\hline
\end{tabular}

Decision-making quality and effectiveness of conciliation process of lupong tagapamayapa. The overall results of the correlation of measures indicate that there is a significant relationship between the two variables. Thus, the null hypothesis will be rejected. This implies that the decisionmaking quality of the lupong is relevant in achieving an effective conciliation process.
However, despite the result that shows that the variables has a correlation and all the indicators having significant relationship, there are still indicators that shows low magnitude of relationship. Issuance of certificate to file action has an r-value of 0.352 which is describe as a low correlation. This indicates that lupong's decision-making does not have an impact in filing certificate to file action before the case or after, either the case is solved or not. On the other hand, conciliation efforts to reconcile parties gained the highest $r$ value which is 0.925 , this indicate that it has a high correlation. This means that the quality of the decisionmaking of lupong greatly affects its efforts to resolve the dispute of the two parties.

The findings of the study corroborate with Sourdin which states that good decision-making is more likely to result in higher outcomes in an alternative dispute resolution, for the reason that the conciliator's mind is prepared in a wider context of the decision-making [8]. Additionally, it validates the research of Bryson which revealed that in doing an effective dispute resolution, the conciliator should have sound decision-making skills and must show impartiality, transparency, accountability, and knowledge of the rules and procedures [23]. Furthermore, it confirms the claim of Agustin which states that the Lupong representatives who follow the right decision-making procedure and their legal mandate and make thorough assessment and evaluation of the case will have a harmonious resolution of disputes [1]. Also, the result finds support with the perspective of Blignaut which revealed that in achieving the appropriate intent of resolving disputes, the decision-makers and facilitators should be wellqualified and have a good understanding of the legal framework, such as knowing the legal procedures in the conciliation process, in which they act to be legitimate and equitable in making decisions [5].

\subsection{Significance of the Influence of Decision-Making Quality towards Effectiveness of Conciliation Process of Lupong Tagapamayapa}

Presented in table 6 is the regression coefficient to test the significant influence of decision-making quality on the effectiveness of conciliation process of lupong tagapamayapa. The model shows the computed F-value of 40.443 with a corresponding P-value of 0.000 which is lower than the 0.05 level of significance. Furthermore, the coefficient of determination which is the r-squared value enfolds that 63 percent of the variance in effectiveness of conciliation process of lupong tagapamayapa was credited to the indicators of decision-making quality, while the remaining 37 percent is the coefficient of alienation, in other words the 37 percent is not covered in the study. In addition, the data illustrates that decision-making quality significantly influences the effectiveness of conciliation process of lupong tagapamayapa, thus, rejecting the null hypothesis.

However, when examined which indicator of decision-making quality best influences the effectiveness of conciliation 
process of lupong tagapamayapa, Evaluation is the indicator that revealed so. The remaining three indicators scored higher than the set significant level, it means that they cannot significantly influence the effectiveness of the conciliation process.

The results prove the proposition of Steptoe-Warren et al., that strategic decision-making competencies are important in the process of achieving a successful conciliation, having a structured decision-making where it is far from biases and external factors, greatly influences the dispute resolution [24]. Moreover, the result also strengthened the claim of Cox et al., where they addressed that engaging in critical thinking would lead to fairer decision-making and strong rational thinking, and this would mean that a conciliator is ready and fully equipped for the conciliation process [22].

As shown in table 6, evaluation gained a sigma value of 0.000 where it means that this domain of decision-making quality significantly influences the effectiveness of conciliation process of lupong tagapamayapa. However, the other three domains which is structured and approach, impact and transparency and communication garnered a sigma value higher than the set significant level which is $0.158,0.319$ and 0.119 , respectively, this suggests that these domains of decision-making quality cannot influence the said dependent variable.

The findings that were revealed confirm the claim of Dietrich that evaluating the factors affecting decision-making is important [15]. Past experiences, a number of cognitive biases, increased engagement and decreasing results, individual differences, including age and socioeconomic status, and personal belief are the factors that influence good decision-making, therefore these factors can give an important impact in the process of conciliation. Furthermore, it also supports the statement of Nikolić, where he proposed that the evaluation of sound rational thinking and effective decisionmaking includes analyzing psychological factors, the internal and external biases, giving relevance to the decision criteria and examining alternative solutions [25]. These are all essential in the effectiveness of the conciliation process if these are practiced well, then it is impossible to commit decision mistakes.

Table VI. Significance on the Decision-Making Quality towards Effectiveness of Conciliation Process of Lupong Tagapamayapa

\begin{tabular}{|c|c|c|c|c|}
\hline \multirow{2}{*}{ Decision-Making Quality } & \multicolumn{5}{|c|}{ Effectiveness of Conciliation Process of } \\
\cline { 2 - 5 } & $B$ & $\beta$ & $t$ & Sig. \\
\hline Structure and Approach & .086 & .125 & 1.424 & .158 \\
\hline Evaluation & .389 & .527 & 5.644 & .000 \\
\hline Impact & .074 & .102 & 1.002 & .319 \\
\hline $\begin{array}{c}\text { Transparency and } \\
\text { Communication }\end{array}$ & .148 & .164 & 1.573 & .119 \\
\hline $\mathrm{R}=.794$ & & & & \\
\hline $\mathrm{R}^{2}=.630$ & & & & \\
\hline $\mathrm{F}=40.443$ & & & & \\
\hline $\mathrm{P}=0.000$ & & & & \\
\hline
\end{tabular}

\section{CONCLUSIONS AND RECOMMENDATIONS}

This study assessed the decision-making quality towards the effectiveness of conciliation process of lupong tagapamayapa. This study's main objective is to determine which domain of decision-making quality significantly influences the effectiveness of conciliation process of lupong tagapamayapa. This study used the descriptive-correlational method of research. Also, this study was conducted in Barangay Tibal-og and it has 100 respondents, who are the constituents of the barangay who availed the services of the lupong. The researchers adopted questionnaires from online sources. The questionnaire was modified through pilot testing to include only the items relevant to the study.

The results has shown that the level of the decision-making quality of lupong tagapamayapa is very high with a mean score of 5.20 and a standard deviation of 0.64 , which is described as always manifested, additionally the results also showed that the level of the effectiveness of conciliation process of lupong tagapamayapa is very high with a mean score of 5.27 and a standard deviation of 0.59 , which can be describe as always manifested. The study also revealed that decision-making quality and effectiveness of conciliation process of lupong tagapamayapa has a positive high significant correlation with an over- all r-value of 0.767 with a p-value of 0.000 . And lastly, the study revealed that evaluation, which is a domain of decision-making quality, gained a sigma value of 0.000 , therefore it significantly influences the effectiveness of conciliation process of lupong tagapamayapa. This enfolds that if the lupong tagapamayapa evaluates their decisions before settling the dispute, then it can lead to a successful and effective conciliation process. The result of the study will be used to make interventions and programs to maintain and continue the efficiency and effectiveness of lupong tagapamayapa. Based on the results the following conclusions are drawn:

1. The level of decision-making quality of the lupong tagapamayapa in terms of its indicators is very high. Therefore, the lupong tagapamayapa in the barangay shows excellent performance in terms of having and making their decisions with regards to the conciliation process and reconciling the two disputing parties.

2. The level of effectiveness of conciliation process of lupong tagapamayapa in terms of its indicators is very high. Therefore, the lupong tagapamayapa in the barangay had shown a deeper understanding of the conciliation process and performed well in conciliating and resolving the dispute of two parties.

3. There is a positive high significant relationship between decision-making quality and effectiveness of conciliation process of lupong tagapamayapa in Barangay Tibal-og. Therefore, the decision making quality among the lupong in the barangay is correlated to the effectiveness of the conciliation process, if the decisions being made is done 
well then it is expected to have a successful and effective dispute resolution.

4. The domain of decision-making quality of the lupong tagapamayapa that significantly influences the effectiveness of the conciliation process is evaluation. Therefore, evaluating the decisions being made, whether if the decisions are influenced by internal or external biases, psychological factors, rational thinking, and emotional factors, greatly influences achieving an effective conciliation process. In other words, it is important for the conciliator or the lupong tagapamayapa to evaluate their decision before reconciling the two parties because evaluating the decision influences the effective conciliation process.

\section{Recommendations}

In light of the findings and conclusions of the study, the following was recommended:

1. The government, specifically the Department of the Interior and Local Government Unit, should continue to implement programs such as seminars and workshops that can help the lupong maintain and sustain their outstanding and successful operations upon the conciliation of two disputing parties.

2. The Barangay Government of Tibal-og where the Lupong Tagapamayapa is located should put emphasis on teaching the lupong the importance of the evaluation of the decisions and the certificate to file action, for the results had shown that they had a low score on this matter.

3. Other barangay governments, they should continue and or improve the evaluation skills of their Lupong Tagapamayapa members since it was found based on the result of this study that this significantly improves their effectiveness as conciliation body of the barangay.

4. The future researchers should think of the other possible variable that may influence the effectiveness of conciliation process of lupong tagapamayapa, for the result had shown that there is still a significant number of coefficient of alienation where the study didn't cover.

\section{ACKNOWLEDGEMENT}

We would like to express our sincere gratitude and heartfelt appreciation to the following individuals and entities whose generous support and cooperation made the writing of this study possible. To Ma'am Rose Ann M. Macabontoc, the Municipal Local Government Operation Officer of Santo Tomas, Davao del Norte and to Hon. Ricky C. Inodio-an the Punong Barangay of Tibal-og, Santo Tomas, Davao del Norte where the study was undertaken, for their warm accommodation during the conduct of this study. To the contributors of this research, for the constant support and for sharing their thoughts and ideas in helping us complete our research paper. And above all, to the Almighty Father, for His unconditional love, and for making all these things possible.

\section{REFERENCES}

[1] Agustin, C. P. (2018). THE EFFECTIVENESS OF CONCILIATION PROCESS: A PRACTICAL WAY OF DELIVERING JUSTICE. Retrieved from: http://www.garph.co.uk/IJARMSS/Feb2018/12.pdf

[2] Mohammed, M. P., \& Caingat, N. C. (2017). Barangay Justice System In Barangay Matatalaib, Tarlac City: An Evaluation (No. 2017-03-21).

Retrievedfrom:http://www.voiceofresearch.org/Doc/Mar2017/Mar- 2017_21.pdf

[3] Local Government Academy (2019,June 03). LGA, OADR partner for basic ADR Training. $\quad$ Retrieved from https://ga.gov.ph/article/lga- oadrpartnerforbasicadrtraining? fbclid=IwAR1 rsxVIIRuFMhEXK7ZI9o rEXIwF5I 9D8R7FG3XxqBqgD8zs9JLsHumLGPA\#

[4] Booth, C., Clemence, M., \& Gariban, S. (2016). ACAS collective conciliation evaluation 2016. Acas Research Paper, 6, 16. Retrieved from: https://archive.acas.org.uk/media/4631/AcasCollective-Conciliation- Evaluation-2016/pdf/Acas-collectiveconciliation-evaluation-2016.pdf

[5] Blignaut, C. (2018). Effectiveness of conciliation as an alternative dispute resolution process in unfair dismissal disputes (Doctoral dissertation, University of Pretoria). Retrieved from: https://repository.up.ac.za/handle/2263/65692

[6] Sam, R. A., Usop, A. M., \& Abubakar-Sam, S. (2013). "Barangay Justice Service System (BJSS) Project as an Alternative Mechanism in Dispute Resolution in Maguindanao, Southern Philippines: A Content Analysis". International Journal of Humanities and Social Science, 193- 199. Retrieved from: https://www.researchgate.net/publication/257840924_Barangay_J ustice_Service_System_BJSS_Project_as_an_Alternative_Mechan ism_in_Dispute_Resolution_in_Maguindanao_Southern_Philippin es_A_Conte $\overline{\text { nt_Analysis }}$

[7] Shinde, U. (2012). Conciliation as an Effective Mode of Alternative Dispute Resolving System. IOSR Journal Of Humanities And Social Science (JHSS) ISSN, 22790837, 22790845. Retrieved from: http://iosrjournals.org/iosr-

jhss/papers/Vol4-issue3/A0430107.pdf

[8] Sourdin, T. (2012). Decision making in ADR: science, sense and sensibility. Sense and Sensibility (January 25, 2012). Retrieved from:

https://pdfs.semanticscholar.org/63bc/fbda8a743706c938043b896 5acbfa3 f14817.pdf

[9] Foley, K., \& Cronin, M. (2015). Professional conciliation in collective labour disputes. Retrieved from: https://www.ilo.org/wcmsp5/groups/public/---europe/---rogeneva/---sro-

budapest/documents/publication/wcms_486213.pdf

[10] Local Government Code of 1991 (PHI). Available from: https://www.officialgazette.gov.ph/downloads/1991/10oct/199110 10-RA- 7160-CCA.pdf

[11] Hansson, S. O. (1994). Decision theory. A brief introduction. Department of Philosophy and the History of technology. Royal Institute of Technology. Stockholm. Retrieved from: https://www.researchgate.net/publication/210642121_Decision_Th eory A_Brief_Introduction

[12] Bennett, S., Hine, L., \& Mazerolle, L. (2018). Procedural justice.[Weblog post]. doi: 10.1093/OBO/9780195396607 Table III. Level of Decision-Making Quality of Lupong Tagapamayapa0241. Retrieved on: November 15, 2019.

[13] Bujar, M., McAuslane, N., Walker, S. R., \& Salek, S. (2017). Evaluating quality of decision-making processes in medicines' development, regulatory review, and health technology assessment: A systematic review of the literature. Frontiers in pharmacology, $8,189$.

[14] Chambers, R. (2009). Consistent Decision Making by Regulators. Council on Licensure, Enforcement and Regulation. Retrieved from: https://www.clearhq.org/resources/09consistent.pdf

[15] Dietrich, C. (2010). Decision making: Factors that influence decision making, heuristics used, and decision outcomes, 
Student Pulse, 2 (2), 1-7. Retirado de http://www. studentpulse. com/a. Retrieved from:

[16] Boyle, I. M., Duffy, A. H., Whitfield, R. I., \& Liu, S. (2012). The impact of resources on decision making. AI EDAM, 26(4), 407423.Retrieved from:https://www.cambridge.org/core/journals/aiedam/article/impact-of-resources-ondecisionmaking/48F56ED447EF3071EF112B06B89DD2FB

[17] OBI, J. N., \& Agwu, M. E. (2017). EFFECTIVE DECISIONMAKING AND ORGANIZATIONAL GOAL ACHIEVEMENT IN A DEPRESSED ECONOMY. International Journal of research and Development Studies, 8(1).

[18] Stangor, C., \& Walinga, J. (2019). 3.5 Psychologists Use Descriptive, Correlational, and Experimental Research Designs to Understand Behaviour. Introduction to Psychology. Retrieved from: https://opentextbc.ca/introductiontopsychology/chapter/2-2psychologists-use-descriptive-correlational-and-experimentalresearch-designs-to-understand-behavior/

[19] Quaranta, J. (2017). Descriptive Correlational Research: Asthma Management by School Nurses. SAGE Publications Ltd.Retrieved from: https://methods.sagepub.com/case/descriptivecorrelational research- asthma-management-school-nurses
[20] Palinkas, L. A., Horwitz, S. M., Green, C. A., Wisdom, J. P., Duan, N., \& Hoagwood, K. (2015). Purposeful sampling for qualitative data collection and analysis in mixed method implementation research. Administration and policy in mental health and mental health services research, 42(5), 533-544. Retrieved from: https://www.ncbi.nlm.nih.gov/pubmed/24193818

[21] Tavakol, M., \& Dennick, R. (2011). Making sense of Cronbach's alpha. International journal of medical education, 2, 53. Retrieved from: https://www.ijme.net/archive/2/cronbachs-alpha.pdf

[22] Cox, K., Strang, L., Sondergaard, S., \& Monsalve, C. G. (2017). Understanding how organisations ensure that their decision making is fair. RAND.

[23] Bryson, D. (2017, February 11). Conciliation. [Web log post]. Retrieved from https://www.adrac.org.au/conciliation

[24] Steptoe-Warren, G., Howat, D., \& Hume, I. (2011). Strategic thinking and decision making: literature review. Journal of Strategy and Management, 4(3), 238-250.

[25] Nikolić, J. (2018). Biases in the decision-making process and possibilities of overcoming them. Ekonomski horizonti, 20(1), 4559. 